\title{
Analisis Pergeseran Perilaku Konsumen Dalam Niat Beli Di Sektor Otomotif E-Commerce Indonesia
}

\author{
Andres Dharma Nurhalim \\ Sekolah TinggiI lmu Ekonomi Wiyatamandala \\ andres@wym.ac.id
}

\begin{abstract}
The growth of active internet users in Indonesia is increasing positively. Smartphone users in Indonesia are projected to be the largest in the world wide. This traction creates opportunity for the presence of e-commerce. Nowadays, e-commerce is not only selling a low involvement product but also selling high involvement product in this study a new car. This study aims to analyze the relationship between social commerce construct to trust and purchase intention, consumer trust to purchase intention and perceived risks, perceived risk to purchase intention and perceived benefit to purchase intention. This study used questionnaire as tools to gather data from 200 respondents who never bought a new car through e-commerce. Partial least squares structure equation modelling (PLS-SEM) is used in this study to analyze the data. The result of this study showed that social commerce construct has influence on trust and purchase intention, other variable such as perceived risk also has influence on purchase intention.
\end{abstract}

Keywords: Social Commerce Construct, Purchase Intention, New Car, Trust, Perceived Risk, Perceived Benefit

\begin{abstract}
ABSTRAK
Pertumbuhan pengguna aktif internet di Indonesia meningkat secara meningkatdaritahunketahun. Pengguna smartphone di Indonesia diproyeksikan menjadi yang terbesar di dunia. Daya tarik ini menciptakan peluang bagi kehadiran e-commerce. Saat ini, e-commerce tidak hanya menjual produk low engagement tetapi juga menjual produk high engagement dalam penelitian ini berupa mobil baru. Penelitian ini bertujuan untuk menganalisis hubungan antara konstruk social commerce dengan kepercayaan dan niat beli, kepercayaan konsumen terhadap niat beli dan persepsi risiko, persepsi risiko terhadap niat membeli dan persepsi manfaat dengan niat membeli. Penelitian ini menggunakan kuesioner sebagai alat untuk mengumpulkan data dari 200 responden yang pernah membeli mobil baru melalui e-commerce. Pemodelan persamaan struktur kuadrat terkecil parsial (PLS-SEM) digunakan dalam penelitian ini untuk menganalisis data. Hasil penelitian menunjukkan bahwa konstruk social commerce berpengaruh terhadap kepercayaan dan niat beli, variabel lain seperti persepsi risiko juga berpengaruh terhadap niat beli.
\end{abstract}

Kata kunci: Social Commerce, Niat Membeli, Mobil Baru, Kepercayaan, Risiko yang Dirasakan, Manfaat yang Dirasakan 


\section{PENDAHULUAN}

E-commerces sekarang ini sudah menjadi fenomena yang mendunia, dimana hampir setiap negara memiliki kehadiran $e$ commerce.Beberapa Negara dengan $e$ commerce besar di pasar seperti Jepang dengan Rakuten, Cina dengan Alibaba dan Taobao.com, Korea Selatan dengan Gmarket dan Coupang, Prancis dengan Odigeo, Rusia dengan Citilink, dan Amazon sebagai e-commerce terbesar di Inggris, AS, dan Jerman. Amazon dan eBay merupakan raksasa e-commerce global dan pada saat ini juga menargetkan pasar agar bias masuk di Indonesia, namun sebagian besar orang Indonesia cenderung mengunjungi ecommerce yang berbasis di Indonesia (Masajeng Rahmiasri, 2017). Pada dasarnya ciri khas dari $\mathrm{B} 2 \mathrm{C}$ e-commerce adalah menjual produk yang berfokus pada kebutuhan konsumen, contohnya HijUp, sebuah e-commerce untuk busana muslim. Platform pada umumnya pada e-commerce yang pada umumnya menjual hampir semua kebutuhan konsumen, seperti Lazada, Blibli, Mataharimall, dan lain-lain. Retail elektronik, misalnya Alfacart, MAP EMALL, dan Klik Indomaret. Daily deal juga merupakan e-commerce yang dibuat khusus untuk para deal-seeker, dalamhal berbagi informasi mengenai promosi terbaru dengan harga yang paling terjangkau, seperti Groupon (yang sekarang rebranding menjadi Fave), Lakupon, OgahRugi.com dan lainlain. Sebagian besar B2Ce-commerce Indonesia didukung oleh investor besar, misalnya Lazada menutup putaran pendanaannya dengan Alibaba sebagai investor utama (Jon Russell, 2016). Blibli yang diakuisisi Ticket.com pada Juni 2017 lalu sepenuhnya dimiliki oleh grup Djarum, dan Matahari Mall dimiliki oleh grup Lippo sebagai investor utama. Menurut (Ho, S., Moursalien, 2015)bisnis e-commerceyang sekaran gini merupakan bisnis yang memang pesaingnya sangat banyak sekali berkembang. Beberapa contoh untuk marketplace adalah Laku6, Bukalapak, Kudoandother. Di dalam marketplace konsumen dapat melakukan transaksi melalui website e-commerce. P2P mengacu pada e-commercepeer to peer tempat pembeli dan penjual yang dapat langsung menghubungi satu sama lain dan melakukan transaksi tanpa perantara. Contoh ecommerce mulai dari Carmudi, Lamudi, OLX dan lainnya. Model B2B merepresentasikan hubungan antara perusahaan dengan perusahaan. Dapat digunakan grosir, pengecer, pabrikan, dan lain-lain. Contoh B2B e-commerce adalah Bizzy, mereka menjual alat tulis ke 
perusahaan. Contoh lain dari B2B $e$ commerce adalah IndoProc, sebuah perusahaan Indonesia yang membantu menyelesaikan masalah pengadaan menggunakan sistem pengadaan. Kehadiran e-commerce di Indonesia terjadi karena pertumbuhan pengguna internet aktif di Indonesia. Pengguna smartphone di Indonesia diproyeksikan menjadi pengguna smartphone terbesar di dunia. Sebuah perusahaan riset pasar bernama GFK (Gesellschaft für Konsumforschung), mengemukakan bahwa 93\% pengguna internet Indonesia menggunakan smartphone untuk mengakses internet rata-rata 5,5 jam sehari (Gary Kim, 2016). Para pelaku ecommerce menganggap hal ini sebagai peluang. Pertumbuhan pengguna internet menjadi pemicu bagi investor untuk ikut terjun dalam persaingan di industri $e$ commerce, khususnya di Indonesia. $E$ commerce di Indonesia biasanya lahir di kota-kota besar karena kebutuhan infrastruktur, komunikasi dan jaringan sebagai tulang punggung utama bisnis. Bigcommerce, sebuah perusahaan riset $e$ commerce menyebutkan bahwa orang yang tinggal di daerah metropolitan lebih cenderung berbelanja secara online sedangkan $38 \%$ orang yang tinggal di daerah pinggiran mengkhawatirkan privasi dan biaya pengiriman. Kehadiran e-commerce di Indonesia juga turut andil dalam mengubah perilaku konsumen dalam membeli suatu produk. Barang yang dijual di e-commerce biasanya lebih murah dibandingkan tokofisik karena dapat menghemat waktu. Mengacu pada Asosiasi Pusat Perbelanjaan di Indonesia disebutkan bahwa jumlah pengunjung mal di kota-kota besar di Indonesia meningkat pada saat liburan (Danang Sugianto, 2017) seperti Ramadhan, Imlek atau bahkan hari raya besar lainnya. Data terbaru dari Asosiasi Pusat Perbelanjaan Indonesia (APPBI) pada tahun 2018 jumlah pengunjung meningkat selama akhir pekan, misalnya Kota Kasablanka pada hari kerja sekitar 65 ribu hingga 85 ribu dan meningkat menjadi 85 ribu hingga 120 ribu di akhir pekan. Kesimpulannya, untuk mengunjungi toko offline membutuhkan lebih banyak uang dan waktu daripada berbelanja melalui toko online (Dwijayanto, 2018). Sementara itu, pengguna e-commerce bisa mendapatkan produk yang sama dengan harga lebih murah dan produk diantar ke tempat tujuan.Penjual online bisa menjual produk yang sama dengan harga lebih murah karena bisa lebih efisien, mengontrol biaya tetap dan biaya variabel yang dapat mempengaruhi biaya barang mereka. Untuk pembeli online, 
biasanya setelah mereka melakukan pemesanan, konsumen memilih bagaimana produk akan dikirim dan pilih pembayaran online yang mereka sukai. Adapun kerugiannya dalam melakukan pembelian secara online adalah konsumen akan sangat bergantung pada TIK (Teknologi, informasi,dan komunikasi), konsumen tidak dapat menyentuh atau mencoba produk, dan ketidakamanan dalam melakukan transaksi bisnis online (Fernandes, 2014). Kehadiran e-commerce diklaim sebagai jawaban bagi masyarakat perkotaan karena efisiensi waktu, kemudahan bertransaksi, dan biasanya harga yang lebih murah. Dengan menggunakan e-commerce, konsumen dapat menghemat waktu dan uang, terlepas dari keuntungan dan peluang kehadiran $e$ commerce di Indonesia, terdapat juga tantangan bagi pelaku e-commerce seperti penerimaan budaya, masalah logistik dan preferensi pembayaran. Pernyataan tersebut juga relevan dengan bagaimana penerimaan budaya orang Indonesia terhadap pembelian online misalnya, isu trust dan fraudmenjadi faktor utama yang membuat orang takut untuk melakukan pembelian secara online. Selain itu, untuk menghindari terjadinya kecurangan dalam transaksi online seperti pencurian data, konsumen lebih memilih cash on delivery sebagai metode pembayaran. Dalam hambatannya ketika bisnis e-commerce ialah masalah logistik yang mana merupakan salah satu masalah yang menjadi tantangan bagi pertumbuhan e-commerce di Indonesia. Indonesia terdiri dari banyak pulau dimana 53\% penduduknya tinggal di perkotaan, secara geografis toko online Indonesia menghadapi persaingan dengan toko fisik dalam hal jalur distribusi, konsumen di pedesaan dapat melakukan pembelian melalui e-commerce dengan tambahan biaya pengiriman sementara mereka dapat membeli barang melalui toko fisik tanpa khawatir tentang biaya pengiriman. Beberapa keuntungan membeli barang melalui toko fisik adalah kemampuan untuk melihat dan merasakan produk, pilihan warna tertentu, dan barang yang disesuaikan. Oleh karena itu, hal ini menciptakan batasan bagi penyedia $e$ commerce untuk memberikan layanan produk mereka. E-commerce B2C biasanya menjual produk dengan keterlibatan rendah, seperti fashion, aksesoris, hobi dan gadget yang berhubungan dengan barang. Saat ini sedang terjadi pergeseran tren $\mathrm{di} e$ commerce $\mathrm{B} 2 \mathrm{C}$ Indonesia seperti Lazada, Blibli, dan Matahari mall yang menjual produk-produk dengan keterlibatan tinggi seperti mobil baru. Sedangkan Lamudi, OLX, Carmudi, Otobursa tergolong $e$ - 
commerce $\mathrm{C} 2 \mathrm{C}$ yang menjual mobil bekas. Bahkan raksasa e-commerce dunia seperti Amazon masih menjual mobil bekas. Menjual mobil baru di B2C e-commerce adalah membantu menjual ulang mobil baru untuk menarik lebih banyak konsumen dengan menggunakan e-commerce sebagai pemasaran multi-saluran. Ada banyak pilihan bagi penjual mobil baru untuk menjualnya melalui saluran online, misalnya bisa mengiklankan mobil barunya di list website atau di marketplace $\mathrm{C} 2 \mathrm{C}$, tapi peluang mendapatkan konsumen yang tepat lebih baik dengan $\mathrm{B} 2 \mathrm{C}$ e-commerce. Mengacu pada wawancara yang dilakukan penulis dengan perwakilan e-commerce, biaya penjualan kendaraan melalui $e$ commerce adalah $4 \%$ per transaksi. Ini terdiri dari biaya komisi, biaya transaksi dan tidak termasuk biaya pengiriman. Perilaku konsumen terhadap niat membeli mobil sering dikategorikan sebagai keterlibatan yang tinggi. Produk dengan keterlibatan tinggi adalah hal-hal yang jarang atau sering dibeli, mahal dan pembeli biasanya bersedia menghabiskan lebih banyak waktu dan tenaga untuk mengumpulkan lebih banyak informasi. Baru-baru ini, laporan Google menunjukkan bahwa $73 \%$ dari 508 responden menggunakan telepon pintar di semua tahap pembelian mobil, terutama ketika potensi pembeli mencari informasi lebih lanjut. Penelitilain juga menunjukkan bahwa $72 \%$ responden mencari informasi melalui situs websitedan membeli mobil melalui dealer, sedangkan 52\% responden mencari dealer melalui situs website. Namun hanya $49 \%$ responden yang bersedia membeli mobil baru melalui jalur online(Herman, 2017). Penjualan mobil online menjadi tren dan ancaman baru bagi tenaga penjual mobil. Produsen mobil di Eropa dan China seperti Jaguar, Hyundai, dan Geely mulai mengurangi penjualan langsung konvensionalnya dan mulai menjual mobil baru secara online, melalui website mereka. Di Indonesia, Tunas Toyota mengatakan melakukan penjualan mobil secara online juga memberikan kontribusi sebesar $10 \%$ dari total penjualan mobil oleh Tunas Toyota. Secara global, tidak ada penelitian yang dipublikasikan secara online untuk membahas tentang niat membeli mobil baru. Sebagian besar membahas tentang faktor-faktor yang mempengaruhi pembelian gadget, asesoris, dan produk terkait fashion melalui e-commerce. $\mathrm{Di}$ Indonesia terdapat penelitian yang membahas tentang perbedaan persepsi risiko toko online vs toko offline. Saat ini belum ada penelitian sebelumnya di Indonesia tentang niat beli mobil baru melalui $e$ - 
commerce. Oleh karena itu, penelitian ini bertujuan untuk menganalisis faktor-faktor yang mempengaruhi minat beli mobil baru melalui e-commerce. Berdasarkan latar belakang dan rumusan masalah yang tertulis pada sub bab sebelumnya, berikut ini adalah daftar pertanyaan yang ingin dijawab oleh peneliti:

1. Apakahe-commerce memengaruhi kepercayaan konsumen?

\section{TELAAH LITERATUR}

E-commerce

Pada dasarnya e-commerce merupakan aplikasi teknologi dengan menggunakan internet dan teknologi web untuk membantu organisasi atau individu menjalankan bisnisnya. (Schneider, G. P., Gosselin, D., 2007) mengatakan bahwa e-commerce menjadi 2 gelombang, gelombang pertama didominasi oleh perusahaan AS dan sebagian besar situs web e-commerce dalam bahasa Inggris, sedangkan gelombang kedua e-commerce ditandai oleh perusahaan global yang berpartisipasi dalam e-commerce. Saat ini, e-commerce tersedia di banyak negara dengan beberapa pilihan bahasa. $E$ commerce menggunakan tiga pendekatan yang berbeda yaitu teknologi, bisnis dan nilai. Pendekatan teknologi, e-commerce
2. Apakahe-commerce memengaruhi niatbeli konsumen?

3. Apakah kepercayaan konsumen mempengaruhi niat beli?

4. Apakah kepercayaan konsumen mempengaruhi persepsi risiko?

5. Apakah risiko yang dipersepsikan pengguna dapat memengaruhi niat beli konsumen? menggunakan penerapan teknologi untuk meningkatkan transaksi bisnis. Pendekatan bisnis, biasanya orang menggunakan $e$ commerce untuk transaksi online. Pendekatan nilai, e-commerce sebagai alat untuk penciptaan nilai. Transaksi $e$ commerce terbesar di Indonesia berasal dari B2B, B2C dan C2C. Perbedaan antara B2B dan B2C adalah pasar sasaran mereka. B2B e-commerce adalah bisnis ke bisnis yang menargetkan perusahaan bisnis sebagai pembeli. B2C adalah bisnis ke konsumen yang menargetkan langsung ke konsumen akhir (Turban et al, 2015). Sedangkan C2C adalah konsumen yang menjual produk ke konsumen lain selain target pasarnya, karakteristik tiap kategorinya juga berbeda. 


\section{Perilaku Konsumen}

Menurut (Kotler, 2000) perilaku konsumen merupakan sebuah studi tentang bagaimana konsumen akan memilih untuk membeli, menggunakan dan mencoba suatu produk atau jasa untuk memenuhi kebutuhan dan keinginannya. Perilaku konsumen merupakan suatu kajian untuk memahami dan menginterpretasikan kebutuhan dan keinginan konsumen terhadap segala jenis produk atau jasa. Perilaku konsumen sebagai aktivitas konsumen untuk mendapatkan, mengonsumsi dan membuang produk dan jasa. Memperoleh berarti membeli atau menerima produk, mengkonsumsi berarti keadaan bagaimana konsumen menggunakan produk, dan membuang sarana bagaimana konsumen membuang produk dan kemasan. Perilaku konsumen dengan pembelanjaan offline berbeda dengan pembelanja online. Pembeli online lebih suka menggunakan $e$-commerce karena menghemat waktu dan tenaga. Pembeli online dapat membeli barang dengan mudah melalui website, dengan membandingkan retail offline yang mereka butuhkan untuk membuat usaha dengan berkendara ke mal dan mencari produk atau barang. Namun, itu membutuhkan lebih banyak waktu dan tenaga. Sedangkan dengan menggunakan $e$ commerce mereka dapat membeli barang dalam beberapa klik. Sebenarnya pada umumnya baik pembeli online maupun offline menghadapi tahapan proses pengambilan keputusan konsumen yang sama. Mengacu pada (Schiffman, L., \& Kanuk, 2010), proses pengambilan keputusan konsumen diklasifikasikan menjadi tiga tahap yaitu tahap input, proses, dan output. Tahap input merupakan tahap dimana konsumen membutuhkan pengenalan terhadap suatu produk. Tahapan tersebut terdiri dari dua sumber informasi utama yaitu upaya pemasaran perusahaan dan sosiologis eksternal. Upaya pemasaran perusahaan terdiri dari bauran pemasaran seperti produk, harga, tempat, promosi. Sosiologis eksternal terdiri dari faktor sosial yang dapat mempengaruhi pengambilan keputusan konsumen seperti keluarga, teman, tetangga, kelas sosial dan budaya keanggotaan. Menurut (Schiffman, L., \& Kanuk, 2010), tahap proses merupakan tahap untuk menganalisis informasi yang dikumpulkan dari tahap sebelumnya. Faktor psikologis berupa motivasi, persepsi, pembelajaran, kepribadian, dan sikap faktor yang mempengaruhi konsumen pada tahap ini. Tahap keluaran dari model pengambilan keputusan konsumen terdiri dari dua kegiatan pasca pengambilan keputusan yang berhubungan yaitu perilaku pembelian dan 
evaluasi pasca pembelian. Perilaku pembelian merupakan hasil dari pengambilan keputusan konsumen, baik untuk membeli produk atau tidak. Evaluasi perilaku pasca pembelian diukur dengan kepuasan konsumen, jika mereka puas dengan produk tersebut, konsumen dapat merekomendasikan produk tersebut kepada calon konsumen lain dan menjadi konsumen setia. Tujuan dari kegiatan tersebut adalah untuk mengetahui tingkat kepuasan konsumen.

\section{Rekomendasi \& Rujukan}

Rekomendasi dan rujukan diartikan sebagai aktivitas online yang melibatkan pertukaran informasi untuk membantu orang mengambil keputusan untuk membeli. Rekomendasi \& rujukan digunakan oleh calon pembeli untuk memahami produk.Dalam perdagangan tradisional, konsumen menggunakan rekomendasi dan rujukan untuk memutuskan produk atau layanan mana yang lebih relevan bagi mereka. Namun, di era e-commerce konsumen bergantung pada rekomendasi dan rujukan konsumen lain karena keterbatasan mereka dalam menikmati produk. Rekomendasi dalam e-commerce dianggap sebagai sumber informasi yang mempengaruhi perilaku konsumen. Forum
\& Komunitas Web 2.0 yang berkembang memberi orang akses untuk membuat komunitas online. Menurut (Hajli, N., 2016), forum dan komunitas adalah kumpulan dari berbagai kelompok yang berbeda sebagai bagian dari komunitas yang saling mendukung dalam satu platform. Dengan kata lain, forum \& komunitas adalah lingkungan sosial yang menampung interaksi sosial individu. Anggota komunitas dapat berbagi pengalaman atau pengetahuan mereka tentang produk atau layanan melalui forum. Alasan utama orang bergabung dengan komunitas online adalah pertukaran informasi.

\section{Rating \& Review}

Rating biasanya berupa angka atau bintang untuk menunjukkan tingkat yang memuaskan terhadap produk atau layanan. Review adalah opini konsumen berdasarkan pengalaman mereka terhadap produk atau jasa. Tinjauan konsumen secara substansial adalah sistem reputasi yang didorong oleh pasar. Review konsumen sangat penting di dalam era e-commerce. Ulasan yang diberikan kepada konsumen akan berdampak pada penjualan dengan berbagi pengalaman dan nilai informasi mereka terhadap produk atau layanan. Sebagian besar konsumen percaya pada penilaian dan 
ulasan dan menggunakannya untuk pertimbangan sebelum membeli barang. Ulasan dapat ditulis oleh profesional atau amatir, tetapi pembeli yang potensial akan lebih memperhatikan pengulas amatir daripada profesional karena merupakan informasi yang independen, kredibel dan berguna. (Yubo, C., 2005) mengatakan bahwa review oleh pihak ketiga berpengaruh signifikan terhadap keputusan pembelian konsumen.

\section{Persepsi Resiko}

Persepsi risiko secara umum sebagai konsep dasar dalam perilaku konsumen yang berimplikasi pada ketidakpastian pengalaman konsumen sebelum pembelian dan bagaimana konsumen membuat asumsi untuk kerugian yang diharapkan dalam pembelian suatu produk dan penggunaan suatu produk. Dimensi risiko yang dirasa mengacu pada Cunningham (1967) adalah ketidakpastian dan konsekuensi. (Naiyi, 2004)mengatakan bahwa terdapat tujuh dimensi pada persepsi resiko antara lain perceived risk yaitu fraud, delivery, financial, process \& time, product, privacy and information risk. Perceived risk diklasifikasikan menjadi enam kategori yaitu risiko fungsional, risiko fisik, risiko finansial, risiko sosial, risiko psikologi, dan risiko waktu. Sedangkan (Tanadi, T., Samadi, B., Gharleghi, 2015), menyederhanakan risiko menjadi empat dimensi yaitu delivery, privacy, qualityand time risk. Perceived benefit merupakan manfaat yang dirasakan yang berkaitan dengan keunggulan konsumen dimana konsumen dapat mencari informasi dengan nyaman tanpa tekanan untuk membeli barang dengan segera. Manfaat yang dirasakan pada dasarnya adalah bagaimana konsumen melihat keuntungan dari memilih toko fisik atau e-commerce. Mengacu pada (Forsythe, S., 2006) manfaat yang dirasakan pada toko fisik dikategorikan sebagai motif fungsional dan motif non fungsional. Motif fungsional berkaitan dengan kenyamanan, variasi dan kualitas suatu produk, dan harga. Motif non-fungsional berkaitan dengan aspek sosial dan emosional seperti kenikmatan dan pengalaman berbelanja. Pada dasarnya manfaat yang dirasakan dalam konteks toko online adalah pertimbangan konsumen untuk menggunakan situs web tertentu berdasarkan tingkat keunggulannya. Lebih lanjut, manfaat yang dirasakan dalam konteks belanja online diartikan sebagai kenyamanan dan penghematan waktu bagi konsumen. Mengacu pada (Katawetawaraks, C., Wang. C, 2011) beberapa produk mudah dijual 
melalui online seperti software dan buku. Namun, ada beberapa produk yang lebih disukai konsumen untuk dibeli secara offline karena keterbatasan situs web itu sendiri. (Katawetawaraks, C., Wang. C, 2011)juga mengklasifikasikan manfaat yang dirasakan dalam belanja online sebagai berikut:

1. Convenience experience: untuk kenyamanan belanja online berarti antarmuka pengguna situs web. Sedangkan untuk belanja fisik, kemudahan adalah fasilitas dan penataan produk. Informasi suatu produk: dalam e-commerce, informasi produk termasuk gambar akan mempengaruhi konsumen untuk membeli, sedangkan di toko fisik, konsumen dapat melihat dan menyentuh produk dan terkadang memakainya (pakaian dalam dan sepatu) dan jika konsumen memiliki pertanyaan dapat menanyakan langsung kepada penanggung jawab produk tersebut diri.

2. Ketersediaan produk dan layanan: $e$ commerce tergantung pada fitur website dan database. Sedangkan untuk toko fisik, jika produk tidak tersedia konsumen dapat membatalkannya secara langsung.
3. Efisiensi biaya dan waktu: untuk $e$ commerce, konsumen dapat melihatlihat produk dan membandingkannya dengan situs lain, sedangkan di toko fisik, untuk membandingkan suatu produk akan membutuhkan waktu, uang dan tenaga yang lebih besar untuk mendapatkan perbandingan yang tepat dari suatu produk karena lokasi bijaksana dan ketidakpastian kemacetan lalu lintas.

(Doney, P.M., Cannon, 1997) mengatakan bahwa kepercayaan merupakan konteks pembelian konsumen dapat mempercayai perusahaan pemasok atau tenaga penjualan. Ada empat aspek untuk membangun kepercayaan dalam pengaturan industri likeretail tradisional yaitu:

1. Kalkulatif: pembeli akan menghitung biaya dan imbalan perusahaan melalui perilaku mereka terhadap reputasi, ukuran, penyesuaian, dan hubungan mereka dengan pemasok dan penjual. Reaksi perusahaan dengan menggunakan kesamaan wiraniaga, kesukaan wiraniaga, seringnya kontak sosial dengan orang sosial

2. Kemampuan: kemampuan suatu perusahaan untuk memenuhi janji. 
Pembeli akan melakukan penilaian melalui keahlian tenaga penjual dan kekuatan tenaga penjual

3. Intentionalitas: perusahaan mempunyai motivasi positif untuk menjalin hubungan dengan pembeli.

4. Transferensi: Pembeli menemukan bukti bahwa perusahaan dapat memenuhi janji dan memutuskan untuk mempercayai perusahaan.

\section{Purchase Intention}

Niat membeli adalah bagian dari pengambilan keputusan konsumen, ketika konsumen sedang mempertimbangkan untuk membeli atau tidak membeli suatu produk atau jasa.(Kotler, 2000) mendefinisikan niat beli sebagai perilaku konsumen terjadi ketika konsumen dirangsang oleh faktor

\section{METODOLOGI PENELITIAN}

Menurut (Zikmund et al, 2013) mengatakan bahwa desain penelitian merupakan kerangka kerja atau rencana induk untuk menentukan langkah demi langkah penelitian. Menurut (Sekaran, U., Bougie, R., 2016), desain penelitian membantu peneliti dalam mengumpulkan data, mengukur, dan menganalisis sebuah penelitian. Jenis penelitian yang dilakukan eksternal dan datang untuk mengambil keputusan berdasarkan karakteristik pribadi dan proses pengambilan keputusan mereka. Selanjutnya (Kotler, 2000)menjelaskan tentang model AIDA yang terdiri dari perhatian, minat, keinginan dan tindakan. Dalam penelitian ini difokuskan pada keinginan yaitu kemauan konsumen untuk mencoba atau memiliki produk, pada tahap ini rasa ingin tahu konsumen dapat mengarah pada minat beli. Sebelum konsumen memutuskan untuk membeli suatu produk, konsumen mencaribeberapa informasi berdasarkan pengalaman pribadi dan eksternal. Konsumen akan memproses informasi dan melakukan evaluasi sebelum memutuskan berdasarkan perbandingan dan penilaian mereka.

penulis adalah untuk mengetahui pengaruh variabel social commerce terhadap trust dan perceived risk serta perceived benefit terhadap minat beli. Sedangkan unit analisis dalam penelitian ini adalah individu, yaitu penyebaran kuesioner kepada pengguna $e$ commerce yang mana untuk time horizon penulis menggunakan cross sectional, untuk mendapatkan jawaban penelitian, penulis 
hanya menyebarkan kuesioner. Kuesioner dilakukan sejak tanggal 25Januari sampai dengan tanggal 15 Februari 2021. Penelitian yang dilakukan penulis dilakukan di daerah Kota Tangerang. Subjek penelitian yang dilakukanpenulis adalahpengguna $e$ commerce khususnya yang belum pernah memiliki pengalaman membeli mobil baru melalui e-commerce. Penelitian ini menggunakan SEM-PLS untuk menganalisis data, dalammengolah data penelitian ini menggunakan data primer yang dikumpulkan melalui kuesioner bagi pengguna e-commerce. Kuesioner dipilih sebagai teknik pengumpulan data karena responden yang tersebar di Kota Tangerang. Mengingat belum diketahui jumlah pengguna e-commerce di Kota Tangerang sebagai populasi sasaran, maka untuk menentukan ukuran pengambilan sampel penelitian ini menggunakan rumus yang dikemukakan oleh (Lemeshow et al, 1990). Rumusnya adalah sebagai berikut menurut Lemeshowformula, diperoleh hasil bahwa sampel minimal untuk penelitian ini adalah 96 sampel.

\section{HASIL DAN PEMBAHASAN}

Tabel 1 Hasiil Responden Berdasarkan Demografi

\begin{tabular}{|c|c|c|c|}
\hline $\begin{array}{l}\text { Demography } \\
\text { characteristics }\end{array}$ & Category & Amorent & Percentange \\
\hline \multirow{2}{*}{ Mast preferred e-commerce } & Id.1.d & 50 & 2800 \\
\hline & $\begin{array}{l}\text { Bubli } \\
\text { Bukal apak }\end{array}$ & 132 & $66 \%$ \\
\hline \multirow{6}{*}{ Age } & Less than 25 & 2 & 196 \\
\hline & $26 \times 030$ & $1+6$ & $73 \%$ \\
\hline & $31 \div 035$ & 30 & 1596 \\
\hline & $3610-40$ & 14 & $70 \%$ \\
\hline & 41 to 45 & 6 & 396 \\
\hline & $\begin{array}{l}\text { Greater than } 46 \\
\text { Femate }\end{array}$ & $\frac{2}{36}$ & $\frac{190}{680}$ \\
\hline Gender & Male & 64 & 3200 \\
\hline \multirow{5}{*}{ Oceupation } & Student & 2 & 190 \\
\hline & Employees & 176 & 8806 \\
\hline & Civil servant & 6 & 306 \\
\hline & Howsewife & 12 & 105 \\
\hline & Others & 2 & $10 \%$ \\
\hline \multirow{3}{*}{ Edmontion } & High school & 10 & 500 \\
\hline & Diploma & 6 & 306 \\
\hline & $s_{2}^{51}$ & $1+4$ & 7200 \\
\hline \multirow{4}{*}{ Place of work } & Sakarta & 124 & 6200 \\
\hline & $\begin{array}{l}\text { Bogor/Depolk/Tangeriang } \\
\text { Beknsi }\end{array}$ & 32 & 1600 \\
\hline & Dut of Java & 44 & 2200 \\
\hline & Others & 0 & 096 \\
\hline \multirow{4}{*}{ Average income } & $\begin{array}{l}\text { RP. } 5.000 .060 \\
10125.000 .000- \\
15.000 .000\end{array}$ & 136 & 6806 \\
\hline & $\begin{array}{l}\text { WDI IS.000.001 - } \\
25.000 .000\end{array}$ & 5.4 & 2790 \\
\hline & $\begin{array}{l}\text { WDR } 25.000 .0011- \\
50.000 .000\end{array}$ & 6 & 396 \\
\hline & 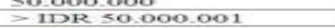 & 2 & $1 \%$ \\
\hline \multirow{5}{*}{$\begin{array}{l}\text { Preferred source of } \\
\text { information to find out about a } \\
\text { product to buy }\end{array}$} & Radio & o & 096 \\
\hline & Newvspaper & 4 & 206 \\
\hline & $\begin{array}{l}\text { Magazine } \\
\text { Search Enowe }\end{array}$ & 186 & $\begin{array}{l}13 \% \\
930 \%\end{array}$ \\
\hline & Social Media & $\frac{180}{6}$ & 3506 \\
\hline & Other: & 2 & 106 \\
\hline \multirow{7}{*}{$\begin{array}{l}\text { Most frequent things to buy in } \\
\text { c-commerce }\end{array}$} & Fashion & 132 & $66 \%$ \\
\hline & $H_{p}<$ Gadser & 150 & $75 \%$ \\
\hline & Computer \& I aptop & 86 & 4306 \\
\hline & Honvehold applianees & 42 & 2106 \\
\hline & $\begin{array}{l}\text { Electronic } \\
\text { Sports of Hobby }\end{array}$ & 30 & 1506 \\
\hline & $\begin{array}{l}\text { Sports L Hoblaby } \\
\text { Antomotive }\end{array}$ & 6 & $\frac{3700}{396}$ \\
\hline & Groceries & 18 & 906 \\
\hline
\end{tabular}


Tabel 2 Hasil Responden Berdasarkan Demografi

\begin{tabular}{|c|c|c|c|}
\hline $\begin{array}{c}\text { Demography } \\
\text { characteristics }\end{array}$ & Category & Amount & Percentage \\
\hline \multirow{4}{*}{$\begin{array}{c}\text { Frequency of shopping } \\
\text { online for the past } 3 \\
\text { months }\end{array}$} & 1-2 times & 120 & $60 \%$ \\
\hline & 3-4 times & 72 & $36 \%$ \\
\hline & 5-6 times & 0 & $0 \%$ \\
\hline & $>7$ times & 8 & $4 \%$ \\
\hline \multirow{5}{*}{$\begin{array}{l}\text { Lastthreemonthsspendi } \\
\text { ngfor Onlineshopping }\end{array}$} & $<$ IDR 1.000.000 & 130 & $65 \%$ \\
\hline & $\begin{array}{c}\text { IDR } 1.000 .000- \\
\text { IDR } \\
5.000 .000\end{array}$ & 62 & $31 \%$ \\
\hline & $\begin{array}{c}\text { IDR 5.000.001 - } \\
\text { IDR } \\
10.000 .000\end{array}$ & 8 & $4 \%$ \\
\hline & $>$ IDR 10.000 .000 & 0 & $0 \%$ \\
\hline & Others & 0 & $0 \%$ \\
\hline \multirow{4}{*}{$\begin{array}{c}\text { Preferred payment } \\
\text { method }\end{array}$} & Credit Card & 64 & $32 \%$ \\
\hline & Bank Transfer & 132 & $66 \%$ \\
\hline & Cash On Delivery & 4 & $2 \%$ \\
\hline & Others & 0 & $0 \%$ \\
\hline
\end{tabular}

Karakteristik Responden Jumlah responden dalam penelitian ini adalah dua ratus (200) responden. Pada tabel di atas menunjukan karakteristik responden yang mana berdasarkan karakteristik responden mayoritas berjenis kelamin perempuan dengan umur 26 sampai dengan 30 tahun, dengan pendapatan rata-rata perbulan berkisar 5 sampai dengan 15 juta rupiah. Responden biasanya menggunakan mesin pencari sebagai sumber informasi untuk mendapatkan detail spesifikasi produk yang diinginkan. Selama tiga bulan terakhir, sebesar 60\% (enam puluh persen) responden memilih 1-2 kali frekuensi berbelanja online dengan kurang dari satu juta. Daftar 5 barang yang paling sering dibeli di $e$ commerce adalah handphone dan gadget (75\%), fashion (66\%), komputer (43\%), olah raga dan hobi (37\%), dan peralatan rumah tangga (21\%). Apalagi, selama tiga bulan terakhir mereka menghabiskan kurang dari satu juta rupiah untuk transaksi e-commerce sedangkan untuk melakukan pembayaran menggunakan metode transfer bank masih lebih disukai sebagai metode pembayaran 
daripada kartu kredit atau menggunakan

pembayaran tunai.

Tabel 3 Hasiil Analisis Coeficient

\begin{tabular}{|c|c|c|c|c|c|}
\hline Hypothesis & Path & $\begin{array}{c}\text { Path } \\
\text { Coeficient }\end{array}$ & T-statistic & P-Values & Conclusion \\
\hline H1 & SCC - T & 0,495 & 6,917 & 0,000 & Supported \\
\hline H2 & SCC - PI & 0,413 & 3,216 & 0,001 & Supported \\
\hline H3 & T - PI & $-0,039$ & 0,389 & 0,697 & Not supported \\
\hline H4 & T - PR & $-0,130$ & 1,557 & 0,120 & Not supported \\
\hline H5 & PR - PI & $-0,280$ & 2,260 & 0,024 & Supported \\
\hline H6 & PB - PI & 0,169 & 1,179 & 0,239 & Not supported \\
\hline
\end{tabular}

Dalam penelitian ini penulis menggunakan tingkat kepercayaan sebesar 95\% dengan yang mana t-value sebesar 1,96. Dalam pengukuran model ini jika dapat di katakana apabila $t$-statistic lebih besar dari 1,96 artinya menunjukan hipotesis tersebut berpengaruh secara signifikan, sebaliknya $t$ statistic lebih kecil artinya menunjukan hipotesis tersebut tidak berpengaruh secara signifikan. Dari uji hipotesis untuk $\mathrm{H}_{1}$ adalah konstruk social commerce (SCC) berpengaruh terhadap kepercayaan konsumen. Mengacu pada tabel tabeldiatas SCC berpengaruh signifikan terhadap kepercayaan konsumen. T-statistik menunjukkan bahwa 6,917 lebih besar dari 1,96. Koefisien jalur untuk $\mathrm{H}_{1}$ adalah 0,495 yang berarti tingkat signifikansi antara SCC dengan $\mathrm{T}$ tinggi, oleh karena itu kesimpulan tersebut menunjukan bahwa social commerce berpengaruh terhadap kepercayaan konsumen. Uji hipotesis $\mathrm{H}_{2}$ adalah konstruk social commerce berpengaruh terhadap niat beli. Mengacu pada tabel di atas SCC memiliki pengaruh yang signifikan terhadap niat beli. T-statistik menunjukkan bahwa 3,216 lebih besar dari 1,96. Koefisien jalur untuk $\mathrm{H}_{2}$ adalah 0,413 yang berarti tingkat signifikansi antara SCC dengan PI tinggi, oleh karena itu kesimpulan tersebut didukung. Uji hipotesis untuk $\mathrm{H}_{3}$ adalah kepercayaan konsumen berpengaruh terhadap niat beli. Mengacu pada tabel di atas kepercayaan konsumen tidak berpengaruh signifikan terhadap niat beli. Tstatistik menunjukkan bahwa 0,389 lebih rendah dari 1,96. Koefisien jalur untuk $\mathrm{H}_{3}$ sebesar -0,039 yang berarti derajat 
signifikansi antara $\mathrm{T}$ dengan PI rendah, sehingga kesimpulannya tidak mendukung. Uji hipotesis untuk $\mathrm{H}_{4}$ adalah kepercayaan konsumen berpengaruh terhadap persepsi risiko. Mengacu pada tabel 4.6, kepercayaan memiliki pengaruh yang signifikan terhadap persepsi risiko. T-statistik menunjukkan bahwa 1,557 lebih kecil dari 1,96. Koefisien jalur untuk $\mathrm{H}_{4}$ adalah $-0,130$ yang berarti tingkat signifikansi antara $\mathrm{T}$ dengan $\mathrm{PR}$ rendah, sehingga kesimpulan tersebut tidak mendukung. Uji hipotesis untuk $\mathrm{H}_{5}$ adalah persepsi risiko berpengaruh terhadap niat beli konsumen. Mengacu pada tabel di atas, kepercayaankonsumen memiliki pengaruh yang signifikan terhadap persepsi risiko. Tstatistik menunjukkan bahwa 2,260 lebih besar dari 1,96. Koefisien jalur untuk $\mathrm{H}_{5}$ adalah $-0,280$ yang berarti tingkat signifikansi antara PR dengan PI tinggi, oleh karena itu kesimpulannya mendukung. Walaupun koefisien antara PR dan PI dalam penelitian ini negatif, namun hipotesis ini didukung karena sifat risiko yang dipersepsikan bersifat negatif artinya semakin rendah risiko maka semakin banyak pembeli yang mau membeli. Uji hipotesis untuk $\mathrm{H}_{6}$ adalah persepsi manfaat konsumen berpengaruh terhadap niat beli. Mengacu pada tabel diatas, persepsi manfaat tidak berpengaruh signifikan terhadap niat beli. $\mathrm{T}$ - statistik menunjukkan bahwa 1,179 lebih rendah dari 1,96. Koefisien jalur untuk $\mathrm{H}_{6}$ adalah 0,169 yang berarti tingkat signifikansi antara PB dengan PI rendah, sehingga kesimpulan tersebut tidak mendukung. Ada enam hipotesis untuk diuji. Mengacu pada hasil analisis data, tiga hipotesis didukung dan tiga lainnya tidak didukung. Penjelasan dari masing-masing hasil hipotesis adalah sebagai berikut:

Hipotesis 1:

Merujuk pada beberapa penelitian (Hajli, N., 2016) ketika orang membaca review, atau dirujuk oleh teman atau menemukan beberapa informasi di komunitas online, pengguna e-commerce cenderung memiliki kemauan untuk membeli produk di $e$ commerce. Hal ini pun mengacu pada penelitian yang dilakukan oleh (Bolton, R, 2013) yang mana generasi $Y$ adalah seseorang yang lahir pada tahun 1981 sampai dengan tahun 1999. Karakteristik responden dalam penelitian ini adalah pembelanja online yang merupakan generasi Y, dengan $73 \%$ responden berusia antara 26 sampai dengan 30 tahun, $88 \%$ responden adalah karyawan, dan $62 \%$ bekerja di wilayah Tangerang. Mengacu Hasil survey Shopback yang telah dipublikasikan Kompas.com tentang perilaku konsumen 
Indonesia terhadap belanja online menyebutkan bahwa $31 \%$ dari total responden lebih suka berbelanja online pada pagi hari antara pukul 09.00 hingga 12.00 dan sebagian besar merupakan generasi $\mathrm{Y}$ dengan karyawan sebagai pekerjaannya. Merujuk pada riset yang dilakukan oleh MasterCard dan dipublikasikan oleh Marketeers.com, generasi Y di Asia Pasifik memiliki daya beli yang kuat dan temuan tersebut juga menyebutkan tentang perilaku generasi Y dalam membeli produk dengan keterlibatan tinggi. Generasi Y memiliki kecenderungan untuk melakukan survei sebelum mengambil keputusan untuk membeli, setidaknya dibutuhkan waktu selama sebulan sebelum konsumen membeli produk tersebut. Dalam penelitian ini sebagian besar responden menggunakan mesin pencari untuk mengetahui produk yang akan mereka beli, oleh karena itu sangat memungkinkan bagi responden untuk melakukan perbandingan harga, survei tentang spesifikasi produk, tentang penjual seperti mencari rating dan review terbaik, dan tentang diskon terbaru. Temuan ini dikonfirmasi melalui wawancara dengan responden sebagai berikut: "Sebagai pembelanja online, pada umumnya setiap konsumen membeli barang secara online, konsumen akan selalu membaca rating dan review untuk mengetahui penjualnya yang memang dapat dipercaya. Konsumen akan membeli produk yang memiliki banyak ulasan danmasukan positif. Dari segi niat beli mobil, sebagai konsumen milenial biasanyaakan membeli lewat e-commerce kalau penjualnya (merchant)dapat dipercaya, ada took resmi di e-commerce dapat memberi konsumen jaminan dan keamanan. Bagi konsumen setidaknya mereka mencari rating dan review yang positif. Dan konsumen akan menghubungi customer service e-commerce untuk memahami prosedurnya, apakah aman membeli dari mereka, mengetahui reputasi penjualnya, sehingga konsumen bisa mendapatkan rekomendasi. Merujuk pada wawancara dengan responden yang lahir pada tahun 1992 yang tergolong generasi Y, terlihat bahwa responden mempercayai $e$ commerce. Jika reputasi penjualnya positif, konsumen akan membeli mobil tersebut. Untuk memeriksa reputasi penjual, responden biasanyamenggunakan rating dan review untuk mendapatkan konfirmasi bahwa penjual tersebut terpercaya. Selanjutnya dalam hal pembelian mobil secara online responden akan menghubungi customer service untuk mengecek reputasi penjual. Responden menggunakan rating dan review sebagai salah satu untuk 
meningkatkan kepercayaan mereka terhadap e-commerce.

Hipotesis 2:

Seperti yang disebutkan dalam banyak penelitian sebelumnya (Yubo, C., 2005)(Hajli, N., 2016) (Gavilan, Diana. Avello, M., Navarro, G, M., 2017) rating dan review, rekomendasi dan referral, forum dan komunitas memiliki pengaruh terhadap niat beli. Mengacu pada riset yang dilakukan MasterCard dan dipublikasikan di Marketeers.com, generasi Y kerap melakukan riset sebelum membeli sebuah produk. Sebagian besar responden dalam penelitian ini menggunakan mesin pencari (93\%) untuk mendapatkan lebih banyak informasi tentang suatu produk. Generasi Y lebih percaya pada user generated content (UGC) daripada iklan. Generasi Y lebih mempercayai pengalaman orang yang pernahsudahmembelidaripada sebuahiklan. Dalam penelitian ini responden adalah pengguna e-commerce yang dianggap sebagai generasi $\mathrm{Y}$, apalagigenerasi $\mathrm{Y}$ tumbuh dengan teknologi. Generasi Y sudah tidak asing lagi untuk mendapatkan banyak informasi dalam sekali klik dengan menggunakan mesin pencari, namun kemungkinan besar konsumen menggunakan seperti berita online, review blogger, atau forum diskusi online untuk mencari suatu produk. Menurut (Bagozzi, R. P. Dholakia, 2002), dalam forum online, anggota grup dapat melakukan interaksi sosial dimana pengguna e-commerce akan mendapatkan rujukan atau rekomendasi yang akan mendukung keputusan mereka untuk membeli atau berperilaku terhadap suatu produk.

\section{Hipotesis 3}

Penelitian sebelumnya (Hajli, N., 2016) bertentangan untuk mendukung hipotesis. Studi tersebut tidak secara khusus menyebutkan tentang produk. Sebagai contoh, penelitian yang ditulis oleh (Hajli, N., 2016) yang dilakukan di Inggris merupakan penelitian yang sangat umum yang menyelidiki perilaku pengguna situs jejaring sosial, bagaimana interaksi pengguna situs jejaring sosial dapat meningkatkan niat beli pengguna, tanpa menyebutkan secara spesifik tentang produk tersebut. yang sedang diamati. (Hajli, N., 2016) menggunakan pengguna Facebook sebagai objek penelitian dalam penelitian ini ingin mencari tahu faktor-faktor apa saja yang mempengaruhi niat beli pengguna Facebook. Sedangkan pada penelitian ini 
yang menjadi objek penelitian adalah mobil baru, yang ternyata calon pembeli memiliki perlakuan yang berbeda ketika akan membeli mobil baru secara online, pengguna e-commerce lebih cenderung berhati-hati. Pertanyaan pertama yang diajukan kepada responden adalah untuk mengetahui perilaku belanja responden. Responden dalam penelitian ini merupakan pembelanja online dan belum pernah memiliki pengalaman membeli mobil baru di e-commerce. Temuan ini dikonfirmasi melalui wawancara dengan responden yang merupakan generasi Y dan seorang pembelanja online: "Saya belanja online untuk beli alat tulis kantor, saya beli barang dari vendor yang sama tiap triwulan dan pakai e-commerce biasa. Saya tidak percaya kita bisa membeli mobil di $e$ commerce, karena saya lebih suka membeli mobil dari dealer resmi karena saya pribadi suka menegosiasikan harga dan mendapatkan lebih banyak keuntungan "(Christian, 32 tahun). Praktik yang umum terjadi di Indonesia, sebagian besar mobil yang hadir secara online baik berupa mobil baru maupun mobil bekas belum memungkinkan untuk dapat melakukan transaksi sepenuhnya secara online.
Hipotesis 4:

Hasil uji hipotesis menunjukkan bahwa kepercayaan terhadap e-commerce tidak berpengaruh signifikan terhadap persepsi risiko. Walaupun beberapa penelitian menemukan bahwa kepercayaan berpengaruh terhadap persepsi risiko, dalam penelitian ini ditemukan bahwa sebagian besar responden tidak mempercayai $e$ commerce untuk membeli mobil baru. Penggunaan e-commerce di Indonesia berbeda dengan negara lain. Di Indonesia, $e$ commerce digunakan sebagai pilihan kedua atau saluran pilihan lain untuk membeli barang. Orang Indonesia cenderung membeli hal-hal yang bisa dilihat, dirasakan, disentuh, dan dicoba. Temuan ini dikonfirmasi melalui wawancara dengan responden yang merupakan pengusaha dan pembelanja online yang aktif: "Saya tidak tertarik untuk membeli mobil melalui $e$ commerce, saya perlu test drive, negosiasi harga, melihat dan mengecek warnanya karena terkadang warna yang ditampilkan di gambar aplikasi / website mungkin berbeda dengan aslinya, biasanya itu kamera trik dengan efek pencahayaan. Menurut saya aneh membeli mobil melalui e-commerce, setidaknya untuk saat ini, saya tidak bisa mempercayai e-commerce untuk membeli mobil baru secara online. " (Michael, 29 
tahun). Berdasarkan wawancara di responden atas menyebutkan bahwa dia tidak mempercayai e-commerce untuk membeli mobil baru. Responden menyebutkan bahwa perlu test drive, negosiasi harga dan pengecekan kondisi fisik mobil, ini merupakan bagian dari risiko yang dirasa menjadi risiko produk tertentu. Menanggapi takut produknya salah atau warnanya berbeda.

\section{Hipotesis 5:}

Temuan ini didukung oleh (Tanadi, T., Samadi, B., Gharleghi, 2015), (Forsythe, S., 2006). (Tanadi, T., Samadi, B., Gharleghi, 2015) menemukan bahwa belanja online dipersepsikan berisiko, dengan kata lain semakin tinggi risiko maka akan lebih sedikit niat untuk membeli dari e-commerce. (Forsythe, S., 2006) menyatakan bahwa resiko produk merupakan faktor utama yang mempengaruhi niat beli pelanggan. Risiko keselamatan memiliki pengaruh yang signifikan terhadap niat membeli. Dalam penelitian ini, risiko produk dan keselamatan merupakan dua komponen risiko yang dipersepsikan yang layak untuk dianalisis lebih lanjut. Risiko keselamatan ditunjukkan oleh pernyataan: "Secara total saya merasa tidak aman untuk membeli mobil di $e$ commerce”. Risiko produk ditunjukkan dengan pernyataan: "Membeli mobil baru di e-commerce berisiko tinggi karena kemungkinan salah mobil atau mobil rusak".

Hipotesis 6:

(Tanadi, T., Samadi, B., Gharleghi, 2015) menyebutkan bahwa persepsi manfaat terhadap minat beli, hal ini bertentangan dengan penelitian ini. Berdasarkan responden, rata-rata responden dalam penelitianini adalah generasi $\mathrm{Y}$. Sebagaimana diketahui perilaku generasi Y dalam perilaku belanja online, konsumen biasanya melakukan survei sebelum membeli suatu produk. Mengacu pada wawancara sebelumnya, memungkinkan untuk mengasumsikan bahwa sebagian besar responden dalam penelitian ini pernah menggunakan e-commerce untuk perbandingan harga tetapi tidak niat untuk membeli mobil di e-commerce. Praktik umum di Indonesia, konsumen cenderung melakukan negosiasi harga dan syarat cicilan dengan dealer. Pedagang di ecommerce bukanlah dealer resmi. Harga beli mobil yang sama secara online tidak ada perbedaan yang signifikan dengan dealer offline. Untuk saat ini tidak ada diskon khusus jika konsumen membeli mobil baru melalui e-commerce. Dibandingkan dengan membeli mobil secara offline, ada human 
touch dimana konsumen dapat bertemu dengan sales person dan melakukan negosiasi harga yang biasanya konsumen ditawari bonus dan pilihan pembayaran

\section{SIMPULAN}

Berdasarkan hasil analisis pada bab sebelumnya, penelitian ini telah menjawab semua pertanyaan penelitian pada bab satu. Penelitian ini menemukan bahwa konstruk social e-commerce berpengaruh terhadap kepercayaan dan minat beli. Selain itu, persepsi risiko berpengaruh terhadap niat beli. Mayoritas responden dalam penelitian ini adalah generasi $\mathrm{Y}$ yang memiliki kecenderungan melakukan penelitian sebelum membeli suatu produk. Fitur sosial dalam e-commerce seperti rating dan review, rekomendasi dan rujukan, dan forum dan komunitas dapat membantu pengguna $e$ commerce untuk memengaruhi kepercayaan dan niat membeli. Mayoritas responden dalam penelitian ini tergolong online shopper yang mana sedikit dalam melakukan transaksi online. Pengguna $e$ commerce perlu mencari review positif untuk mempercayai e-commerce. Pengguna e-commerce menggunakan forum diskusi untuk mendapatkan lebih banyak temuan positif yang akan meningkatkan minat beli seperti cash, lending atau benefit jika mereka membayar secara tunai (dibayar penuh).

mereka. Responden dalam penelitian ini menyadari adanya risiko berbelanja online. Risiko produk dan risiko keselamatan menjadi perhatian utama atas persepsi risiko yang mempengaruhi niat beli pengguna $e$ commerce untuk membeli mobil baru. Ketidakpastian apakah mobil akan dikirim dengan aman atau tidak, pada akhirnya mobil akantetap dikirim tetapi apabila ada komponen yang rusak merupakan beberapa hal yang menjadi perhatian. Sementara itu, hasil temuan lain dalam penelitian ini adalah kepercayaan tidak berpengaruh terhadap niat beli dan persepsi risiko. Manfaat yang dirasakan juga tidak memiliki pengaruh tentang niat membeli. Temuan dalam penelitian ini menunjukkan bahwa membeli mobil baru melalui e-commerce merupakan hal baru bagi masyarakat Indonesia dimana mereka belum terbiasa dengan kemungkinan untuk membeli mobil baru di e-commerce karena kebiasaan masyarakat Indonesia yang suka bertemu dengan tenaga penjual secara umum. Mulaidaribernegosiasi tentang harga, memeriksa mobil sendiridankebutuhan test drive sebuah mobil sangat penting bagi para 


\begin{abstract}
pengguna e-commerce. Responden mayoritas dalam penelitian ini juga mengungkapkan bahwa konsumen menggunakan e-commerce untuk pengecekan dan perbandingan harga tetapi tidak ada niat untuk membeli mobil baru di e-commerce. Penelitian ini memiliki beberapa keterbatasan. Mengingat jumlah sampel dalam penelitian ini relatif sedikit. Penelitian ini mungkinakan memberikan hasil yang lebih baik jika sampelnya lebih besar. Lokasi yang berbeda juga akan berkontribusi pada hasil yang berbeda. Jika kuesioner disebarkan di daerah terpencil, hasilnya mungkin berbeda. Kemungkinan
\end{abstract}

\section{DAFTAR PUSTAKA}

Bagozzi, R. P. Dholakia, U. M. (2002).

Intentional social action in virtualcommunities. Journal of Interactive Marketing, 16(2), 2-21.

Bolton, R, N et al. (2013). Understanding Generation Y and their use of social media: a review and research agenda. Journal of Service Management, 24(3), 245-267.

Danang Sugianto. (2017). Pengelola: Mal Penuh Biasanya Setelah THR Cair. https://finance.detik.com/industri/d3519839/pengelola-mal-penuh-biasanya- orang yang tinggal di perkotaan berbeda dengan orang yang tinggal di daerah terpencil. Semakin luas cakupan penyebaran kuisioner maka profil responden semakin beragam. Berdasarkan penelitian ini, terdapat beberapa peningkatan peluang studi di masa mendatang. Konsep serupa dapat digunakan untuk berbagai jenis produk highengagement seperti tas dan perhiasan mewah (emas, perak dan berlian). Oleh karena itu peneliti lain akan mendapatkan lebih banyak responden dan mempelajari perilakunya terhadap high engagement product.

setelah-thr-cair

Doney, P.M., Cannon, J. . (1997). An Examination of the Nature of Trust in Buyer Seller Relationships. Journal of Marketing, 35-51.

Dwijayanto. (2018). APPBI : Rerata kunjungan mall capai 30.000 orang per hari.

https://industri.kontan.co.id/news/appbi -rerata-kunjungan-mall-capai-30000orang-per-hari 
Fernandes, J. (2014). Types of e-commerce. https://bloomidea.com/en/blog/types-ecommerce

Forsythe, S., et al. (2006). Development of a scale to measure the perceived benefits and risks of online shopping. Journal of Interactive Marketing.

Gary Kim. (2016, April). 93\% of Indonesian Consumer Internet Access is From Smartphones. https://spectrumfutures.org/93-ofindonesian-consumer-internet-accessis-from-smartphones/

Gavilan, Diana. Avello, M., Navarro, G, M. (2017). The influence of online ratings and reviews on hotel booking. Tourism Management.

Hajli, N., et al. (2016). A social commerce investigation of the role of trust in a social networking site on purchase intentions. Journal of Business Research.

Herman. (2017). Riset Google Ungkap Karakter Pembeli Mobil di Indonesia. http://www.beritasatu.com/digitallife/424585-riset-google-ungkapkarakter-pembeli-mobil-diindonesia.html
Ho, S., Moursalien, F. (2015). 10 Trends That Will Shape Southeast Asian ECommerce in 2016. https://techcrunch.com/2015/12/24/10predictions-for-southeast-asia-ecommerce-in-2016/

Jon Russell. (2016, April). Alibaba's $\$ 1 B$ investment came just in time for cashstrapped Lazada. https://techcrunch.com/2016/04/13/aliz ada/

Katawetawaraks, C., Wang. C, L. (2011). Online Shopper Behavior: Influences of Online Shopping Decision. Asian Journal of Business Research.

Kotler, P. (2000). Marketing Management (10th ed.). Prentice-Hall.

Lemeshow et al. (1990). Adequacy of sample size in health studies.

Masajeng Rahmiasri. (2017, May). Local ecommerce still king for Indonesian shoppers. https://www.thejakartapost.com/life/20 17/05/14/local-e-commerce-still-kingfor-indonesian-shoppers-report.html Naiyi. (2004). Dimensions of Consumer's Perceived Risk in Online Shopping. Journal OfElectronic Science and 
Technology of China, 2(3).

Schiffman, L., \& Kanuk, L. L. (2010). Consumer Behavior, Global Tenth Edition. (10th ed.). Pearson Education, Inc.

Schneider, G. P., Gosselin, D. (2007). Electronic Commerce (7th ed.). Cengage Learning.

Sekaran, U., Bougie, R. (2016). Research Methods for Business: A Skill Building Approach (7th ed.). Wiley.

Tanadi, T., Samadi, B., Gharleghi, B. (2015). The impact of perceived risk and perceived benefits to improve an online intention among generation $\mathrm{Y}$ in Malaysia. Asian Social Science., 11(6).

Turban et al. (2015). Electronic commerce: a managerial and social network perspective (8th ed.). Springer.

Yubo, C., \& J. (2005). (2005). Third-party product review and firm marketing strategy. Marketing Science., 24(2), 218-240.

Zikmund et al. (2013). Business Research Methods (9th ed.). Cengage Learning. 